\title{
Exemption Tests in Library Education
}

\begin{abstract}
Exemption tests have sometimes been used in library schools to enable persons with adequate knowledge of a subject, either from previous study or experience, to eliminate otherwise required courses from their programs. In an effort to determine their value, the Graduate School of Library Science at Drexel Institute of Technology studied the results of exemption tests taken there in 1962, 1963, 1964, and 1965. Circumstances under which they were taken, the ratio of passes to failures, and their correlation with previous study and experience are described. Conclusions are given.
\end{abstract}

\section{BACKGROUND}

\begin{abstract}
A
DISTINCTIVE FEATURE of graduate library education is the widely varying backgrounds brought by students to the program-both in terms of previous library experience and library education. The existence of both graduate and undergraduate library education creates a situation in which some students enter graduate school after having completed undergraduate courses closely paralleling part of the graduate curriculum. While occasionally, students with undergraduate course work matriculate directly from college, more often they obtain library experience before entering graduate school. In addition, despite the profession's emphasis upon separation of professional from nonprofessional tasks, in many libraries personnel without library education perform both kinds of duties. In this way, many students have learned much about library objectives and procedures. Thus, while some grad-
\end{abstract}

Miss Hamsher is Children's Librarian in the Radnor Township Memorial Library in Wayne, Pennsylvania; Dr. Harvey is Chairman of the Department of Library Science in the University of Tehran in Iran. uate library science students have been only library patrons, others bring to graduate work considerable experience or undergraduate library science course work, or, frequently, both.

To allow for this variance in student backgrounds and to avoid the criticism of requiring students to repeat course work already covered, the Drexel Institute of Technology Graduate School of Library Science devised a system of exemption examinations. Before or during his first six weeks of Drexel course work, a student who felt competent in a particular course area might take an exemption test covering that area. If, on either of two attempts he passed the exemption test, he was exempted from the course and given credit for it. In general, only the basic core courses required of all students were exempted, although occasionally, due to special experience or preparation, students were given permission to take examinations in such other subjects as School Library Administration or Reference Materials in the Humanities. At present, four basic courses are required of all students: Library in Society, the historical development of libraries and their role in today's society; Basic Reference Sources; 
Introduction to Cataloging and Classification; and Selection of Library Materials. Previous to the college year 19631964 there was a fifth basic required course-Introduction to Library Service -which provided an orientation to librarianship, but with the Fall term 1963 its content was incorporated into other courses.

Such exemption examinations were not new in higher education nor even in library education, but Drexel's application of them may have been more extensive than usually has occurred. Michigan State University has used exemption testing extensively in its Basic College to allow students to take final sequential course tests one or more terms earlier than was scheduled, and if passed successfully, the student was given credit and exempted from the remainder of the course. ${ }^{1}$ The University of California at Davis has awarded credit to beginning freshmen who passed successfully the CEEB Advanced Placement Examination and allowed them to take more advanced courses. $^{2}$ The University of Chicago College examination program of the 1930's and 1940's was famous. Advancement in the college was based on passing examinations rather than on course work, and the student who could pass examinations faster than the average could graduate sooner. ${ }^{3}$

Other library schools have used such tests, but there seems to be no recent literature on it. Shearhouse comments that librarians have not generally foreseen the use of standardized tests, there being few if any available on a graduate level. Illinois, Peabody, Albany, Denver, and Columbia have had such experi-

\footnotetext{
${ }^{1}$ L. A. Haak, "Acceleration by Examination," College and University, XXIX (October 1953), 39-53.

${ }^{2}$ S. E. Wayne, "Advanced Standing Credit Based on the Advanced Placement Examination at the University of California at Davis," College and University, XLIII (Spring 1967), 308-24.

${ }^{3}$ Jane Allison and Benjamin Bloom, "The Operation and Evaluation of a College Testing Program," Journal of General Education, IV (April 1950), 22133.
}

ence. At Denver such tests were used extensively in the 1930 's, and students who scored well on them were excused from the particular course and given credit for it. All tests in these schools (except Columbia) were constructed by individual faculty members, as at Drexel. $^{4}$

\section{ExAMINATIONS TAKEN}

In order to evaluate the Drexel exemption system and gain an insight into its use, the 1962-65 examinations were studied. During this four-year period a total of 481 examinations were taken by 252 students, so students using the exemption system averaged 1.9 examinations a piece. Some 48 per cent of the examinations taken were passed. The greatest number of examinations was taken in 1962,216 , or seventy examinations per one hundred students enrolled (using the Spring Quarter enrollment figures as the standard), as shown in Table 1 . Thirty-one tests or 12 per cent of the total number taken in four years were retests. Apparently, the chances of passing a test on the second attempt were not much better than on the first attempt, with 52 per cent of the retests being passed.

In 1963, although enrollment had increased by 39 per cent, the number of examinations taken decreased by 36 per cent and the ratio taken per one hun-

\section{TABLE 1}

Number of Drexel Exemption Examinations Taken Each Year Per 100 Students

\begin{tabular}{cccc}
\hline Year & $\begin{array}{c}\text { Number of } \\
\text { Students Enrolled } \\
\text { in Spring } \\
\text { Quarter }\end{array}$ & $\begin{array}{c}\text { Number of } \\
\text { Examinations } \\
\text { Taken }\end{array}$ & $\begin{array}{c}\text { Examinations } \\
\text { Taken Per } \\
\text { Each 100 } \\
\text { Students }\end{array}$ \\
\hline 1962 & 216 & 152 & 70 \\
1963 & 291 & 97 & 33 \\
1964 & 374 & 115 & 31 \\
1965 & 403 & $\underline{117}$ & 29 \\
\hline
\end{tabular}

"Henry Shearhouse, "University of Illinois Library School Placement Examination," Journal of Educational Research XLIV (March 1951), 481-9. 
dred students decreased to thirty-three. In 1964 and 1965 the number of examinations taken rose slightly, but the ratio taken per one hundred students continued to drop, to thirty-one in 1964 and twenty-nine in 1965.

One explanation for the sharp drop between 1962 and 1963 was that Introduction to Library Service was a course which many students attempted to exempt, often successfully. In 1962, it accounted for one-third of the examinations taken and was passed 70 per cent of the time. With the school year 19631964 this course was dropped from the curriculum, so in 1963 it accounted for only one-fifth of the examinations. If we temporarily exclude the figures for Introduction of Library Service and consider only those for the four basic examinations offered throughout the entire four-year period, the ratio of examinations taken per one hundred students in 1962 through 1965 becomes forty, twenty-five, twenty-nine, twenty-eight. There is still a definite drop between 1962 and the following years, but the difference is reduced. Perhaps their novelty in 1962 attracted more students to the exemption tests than in later years.

\section{RAtios}

What was the rate of successful completion? Over a seven-year period Haak found the students in one of the Michigan State University Basic College courses, Effective Living, to have included 18 per cent of the students enrolled in the Basic College courses, and that 94 per cent who took the examination early passed. ${ }^{5}$ Wayne found 49 per cent of those who took the Advanced Placement Examination to have passed it. ${ }^{6}$ In 1948 Illinois embarked on a program of exemption test development to cover its undergraduate library science prerequisites. Of the forty-four students reported to have taken the tests, seven were exempted from courses, and some from all of the core course program. ${ }^{7}$

The rate of successful Drexel examination completion was considerably lower at the end of the period than at the beginning, but in this case there was a pattern not of sudden change but of steady decline (see Table 2). In 1962 59 per cent of the examinations taken were passed, in 1963 the rate was down to 48 per cent, in 1964 to 43 per cent, and in 1965 only 38 per cent were passed. It is clear, then, that in 1963, 1964, and 1965, there were considerably fewer examinations taken in relation to enrollment than in 1962, and that each year the examinations were

${ }^{5}$ Haak, op. cit., 39-53.

6 Wayne, op. cit., 308-24.

' Shearhouse, op. cit. 481-9.

TABLE 2

Successful Completion Rate for Each Course

\begin{tabular}{|c|c|c|c|c|c|c|c|c|}
\hline Course & & & & $\begin{array}{l}1962 \\
\text { Per Cent } \\
\text { of Time } \\
\text { Passed }\end{array}$ & $\begin{array}{c}1963 \\
\text { Per Cent } \\
\text { of Time } \\
\text { Passed }\end{array}$ & $\begin{array}{c}1964 \\
\text { Per Cent } \\
\text { of Time } \\
\text { Passed }\end{array}$ & $\begin{array}{l}1965 \\
\text { Per Cent } \\
\text { of Time } \\
\text { Passed }\end{array}$ & $\begin{array}{l}\text { Total } \\
\text { Per Cent } \\
\text { of Time } \\
\text { Passed }\end{array}$ \\
\hline Library in Society & . & . & . & 64 & 70 & 59 & 39 & 58 \\
\hline Cataloging and & & & & & 40 & 10 & 1 & \\
\hline Basic Reference & . & . & : & 55 & 45 & $\begin{array}{l}19 \\
52\end{array}$ & $\begin{array}{l}21 \\
71\end{array}$ & $\begin{array}{l}23 \\
57\end{array}$ \\
\hline $\begin{array}{l}\text { Selection of Library } \\
\text { Materials } \\
\text { Introduction to }\end{array}$ & . & . & . & 31 & 18 & 27 & 11 & 20 \\
\hline $\begin{array}{l}\text { Library Service } \\
\text { Advanced Courses }\end{array}$ & . & : & & $\begin{array}{l}70 \\
85\end{array}$ & $\begin{array}{l}65 \\
20\end{array}$ & $\begin{array}{c}\text { not offered } \\
60\end{array}$ & $\begin{array}{c}\text { not offered } \\
50\end{array}$ & $\begin{array}{l}68 \\
63\end{array}$ \\
\hline TOTAL & . & . & . & $\overline{59}$ & $\overline{48}$ & $\overline{43}$ & $\overline{38}$ & $\overline{48}$ \\
\hline
\end{tabular}


failed more frequently than the year before. Apparently, either standards for successful completion of the examinations went up or the quality of students deteriorated. Evidence from the Drexel Admissions Office suggests that qualifications improved and the School became more selective during this period, so apparently faculty members made the examinations more difficult to pass.

In considering the frequency with which each course examination was taken and the frequency with which each was passed, it is not surprising to find a correlation between the two: in general those examinations on which students were most often successful were those most frequently attempted. Apparently word got around among the students about the levels of difficulty of the examinations. We have already seen that the examination for Introduction to Library Service, which was taken far more frequently than any other in 1962, was also passed with considerably more frequency than any other. Similarly, of the four basic examinations taken over the entire four-year period, the two most frequently taken were also the two with the highest rate of successful completion. Library in Society and Basic Reference, each of which accounts for 23 per cent of the total number of examinations taken, were also the ones most frequently passed, 58 per cent and 57 per cent respectively (see Table 3). In comparison, over the four-year period Introduction of Cataloging and Classification accounted for 17 per cent of the total number of examinations taken and Selection of Library Materials for 16 per cent, and both were failed four of every five times they were taken. However, even though there is a correlation between the frequency with which the examinations were taken and the frequency with which they were passed, it should be noted that the variance between the two most frequently taken examinations and the two least frequently taken is considerably greater in terms of success rate than it is in terms of frequency rate.

\section{Were Previous Experience and Library Education Helpful?}

As previously mentioned, one of the prime reasons for using exemption tests

TABLE 3

Number of Times Each Examination Taken and Its Percentage of the Total Number of Examinations Taken That Year

\begin{tabular}{|c|c|c|c|c|c|c|c|c|c|c|}
\hline COURSE & $\begin{array}{c}196 \\
\text { Number } \\
\text { of Times } \\
\text { Examina- } \\
\text { tion } \\
\text { Taken }\end{array}$ & $\begin{array}{l}62 \\
\text { Per Cent } \\
\text { of Total }\end{array}$ & $\begin{array}{c}196 \\
\text { Number } \\
\text { of Times } \\
\text { Examina- } \\
\text { tion } \\
\text { Taken }\end{array}$ & $\begin{array}{l}63 \\
\text { Per Cent } \\
\text { of Total }\end{array}$ & $\begin{array}{c}196 \\
\text { Number } \\
\text { of Times } \\
\text { Examina } \\
\text { tion } \\
\text { Taken }\end{array}$ & $\begin{array}{l}\text { res } \\
\text { rs } \\
\text { a- } \\
\text { Per Cent } \\
\text { of Total }\end{array}$ & $\begin{array}{c}19 \\
\text { Number } \\
\text { of Times } \\
\text { Examina- } \\
\text { tion } \\
\text { Taken }\end{array}$ & $\begin{array}{l}65 \\
\text { Per Cent } \\
\text { of Total }\end{array}$ & $\begin{array}{c}\text { TotA } \\
\text { Number } \\
\text { of Times } \\
\text { Examina- } \\
\text { tion } \\
\text { Taken }\end{array}$ & $\begin{array}{l}\text { IL } \\
\text { Per Cent } \\
\text { of Total }\end{array}$ \\
\hline $\begin{array}{l}\text { Library in } \\
\text { Society } \\
\text { Cataloging and }\end{array}$ & 25 & 16 & 23 & 24 & 41 & 36 & 23 & 20 & 112 & 23 \\
\hline Classification & 16 & 10 & 10 & 10 & 27 & 23 & 28 & 24 & 81 & 17 \\
\hline $\begin{array}{l}\text { Basic Reference } \\
\text { Selection of }\end{array}$ & 29 & 19 & 22 & 23 & 27 & 24 & 34 & 29 & 112 & 23 \\
\hline $\begin{array}{l}\text { Library } \\
\text { Materials } \\
\text { Introduction to }\end{array}$ & 16 & 11 & 17 & 17 & 15 & 13 & 28 & 24 & 76 & 16 \\
\hline $\begin{array}{r}\text { Library } \\
\text { Service } \\
\text { Advanced }\end{array}$ & 53 & 35 & 20 & 21 & not & offered & \multicolumn{2}{|c|}{ not offered } & 73 & 15 \\
\hline Courses & 13 & 9 & 5 & 5 & 5 & 4 & 7 & 3 & 27 & 6 \\
\hline TOTAL & $\overline{152}$ & 100 & $\overline{97}$ & $\overline{100}$ & $\overline{115}$ & $\overline{100}$ & $\overline{117}$ & $\overline{100}$ & $\overline{481}$ & $\overline{100}$ \\
\hline
\end{tabular}


TABLE 4

Number of Students in Each Category and Number of Examinations Taken By Students in Each Category

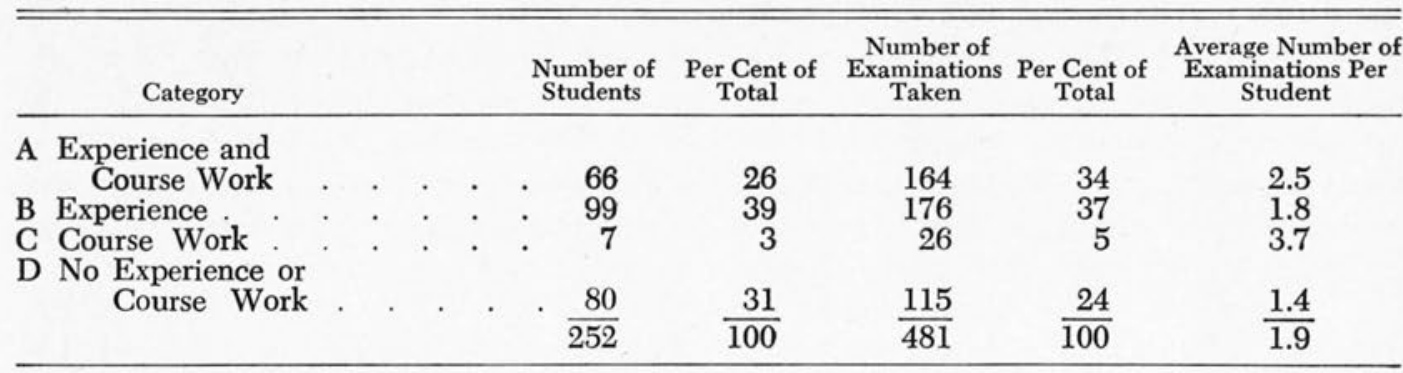

was to allow for the differences in previous experience and library science course work which incoming students brought to graduate school. Naturally the assumption was that such experience and education would assist the student in passing the examination. What was experience in other fields? Allison and Bloom found the number of previous courses in a subject to correlate positively with success on Chicago examinations. $^{8}$ Ostlund tested science teachers to find a positive correlation between course work background in a subject and knowledge of it. He concluded that background and achievement were related predictably and that "as one increased in background and experience, subject matter and reason-

Allison and Bloom, op. cit., 221-33. ing became augmented concomitantly." ${ }^{9}$

In order to see what effect previous experience had on the examinations, the Drexel students who had taken them were divided into four categories (see Tables 4 and 5). Group A was composed of students who had had both previous library science course work and working library experience. Group B consisted of students with working library experience but no library science course work; Group C of students who had had previous course work, but no library experience; and Group D of those students who had had neither experience nor course work. No attempt was made to distinguish between previous

'Leonard Ostlund, "College Transcripts and Standardized Tests as Criteria for Graduate Placement," School and Society, LXXXIV (January 18, 1958), 41-3.

TABLE 5

Successful Completion Rates for Each Category of Student

\begin{tabular}{|c|c|c|c|c|c|c|}
\hline Course & & $\begin{array}{c}\text { Group A } \\
\text { Per Cent of } \\
\text { Times } \\
\text { Passed }\end{array}$ & $\begin{array}{l}\text { Group B } \\
\text { Per Cent of } \\
\text { Times } \\
\text { Passed }\end{array}$ & $\begin{array}{c}\text { Group C } \\
\text { Per Cent of } \\
\text { Times } \\
\text { Passed }\end{array}$ & $\begin{array}{l}\text { Group D } \\
\text { Per Cent of } \\
\text { Times } \\
\text { Passed }\end{array}$ & $\begin{array}{l}\text { Total } \\
\text { Per Cent of } \\
\text { Times } \\
\text { Passed }\end{array}$ \\
\hline Library in Society & . & 45 & 43 & 50 & 83 & 58 \\
\hline $\begin{array}{l}\text { Cataloging and } \\
\text { Classification }\end{array}$ & & 14 & 36 & 43 & 10 & 23 \\
\hline $\begin{array}{l}\text { Basic Reference } \\
\text { Selection of Library }\end{array}$ & & 53 & 48 & 84 & 79 & 57 \\
\hline $\begin{array}{l}\text { Materials } \\
\text { Introduction to Library }\end{array}$ & · & 23 & 17 & 0 & 29 & 20 \\
\hline Service & . & 85 & 58 & 100 & 73 & 68 \\
\hline Advanced Courses & . & 67 & 73 & 0 & 33 & 63 \\
\hline TOTAL & . & 40 & $\overline{45}$ & $\overline{42}$ & $\overline{64}$ & $\overline{48}$ \\
\hline
\end{tabular}


graduate or undergraduate course work. However, it may be assumed that the course work was usually undergraduate, because graduate courses could be transferred into Drexel, thereby eliminating the need to take exemption examinations. It would seem logical that the majority of the students taking examinations would have had previous course work or experience, and this was the case, with Group A accounting for 26 per cent and Group B for 39 per cent. However, a surprisingly large minority ( 31 per cent) belonged to Group D. Group C consisted of only 3 per cent of the total number.

Of the four groups, students in Group $\mathrm{C}$ tended to take the largest number of examinations, averaging 3.7 examinations each, while students in Group D who were the most successful on the examinations taken, attempted the fewest number, only 1.4 each. Perhaps this group attempted only the examinations they were confident of passing. It is interesting, also, that the number of examinations taken by Group D decreased markedly over the period studied, in 1962 accounting for 30 per cent of the total taken; in 1963, 35 per cent; in 1964 , 20 per cent; and in 1965 only 10 per cent. Perhaps this group was quite sensitive to the increasing difficulty of the examinations, or perhaps the school administration began to discourage such students from taking the examinations.

Although theoretically it would seem that students with previous experience or course work would be most successful on the examinations, the results did not bear this out. It was found instead, that of the total number of examinations taken by students in Group D, 64 per cent were passed, while students in Group B passed only 45 per cent and students in Group A, with previous working experience and course work, passed only 40 per cent of the examinations taken. Group C took twenty-six examinations and passed 42 per cent of them. Appar- ently neither the students' previous experience nor course work was sufficiently similar to Drexel course work to be particularly helpful.

Students in Group D did extremely well on the examinations for Library in Society and Basic Reference, and reasonably well on Introduction to Library Service, but this was true also for Groups A and B. However, Group D was able to pass only 10 per cent of the Introduction to Cataloging and Classification examinations which they took. Group A did only slightly better, passing this examination only 14 per cent of the time, but Group B was relatively successful, passing it 36 per cent of the time, presumably showing the value of experience. Perhaps Group A was overconfident because of their course work background, so took more examinations than they were well prepared for.

In considering the frequency with which the examinations were taken by each group of students, we find a correlation with the frequency of successful completion for Groups B and D, but not for Groups C and A (see Table 6).

\section{Success for Specific Colleges}

As a sidelight to the student success based on previous course work, it was possible to determine the success of the graduates of particular undergraduate departments of library science in the Philadelphia area. These results are shown in Table 7. The graduates of two colleges had reasonably good success, and the graduates of two others did not. However, no group of graduates was successful more than 57 per cent of the time, and for the four colleges together the percentage of success was only 40 per cent, lower than the overall average. Apparently these students were overconfident and their undergraduate course work not as suitable as expected in preparing them for Drexel graduate work. Their overconfidence was shown by the fact that they took more exami- 
TABLE 6

Number of Times Examination Taken by Members of a Category and its Percentage of Total Number of Examinations Taken by Members of that Category

\begin{tabular}{|c|c|c|c|c|c|c|c|c|c|}
\hline Course & & $\begin{array}{c}\text { Grou } \\
\text { Number } \\
\text { of Times } \\
\text { Examina- } \\
\text { tion } \\
\text { Taken }\end{array}$ & $\begin{array}{l}\text { P A } \\
\text { Per Cent } \\
\text { of Total }\end{array}$ & $\begin{array}{l}\text { Grou } \\
\text { Number } \\
\text { of Times } \\
\text { Examina- } \\
\text { tion } \\
\text { Taken }\end{array}$ & $\begin{array}{l}\text { P B } \\
\begin{array}{l}\text { Per Cent } \\
\text { of Total }\end{array}\end{array}$ & $\begin{array}{c}\text { Grou } \\
\text { Number } \\
\text { of Times } \\
\text { Examina- } \\
\text { tion } \\
\text { Taken }\end{array}$ & $\begin{array}{l}\text { P C } \\
\begin{array}{l}\text { Per Cent } \\
\text { of Total }\end{array}\end{array}$ & $\begin{array}{l}\text { Grou } \\
\text { Number } \\
\text { of Times } \\
\text { Examina- } \\
\text { tion } \\
\text { Taken }\end{array}$ & $\begin{array}{l}\text { Per Cent } \\
\text { of Total }\end{array}$ \\
\hline $\begin{array}{l}\text { Library in Society } \\
\text { Cataloging and }\end{array}$ & & 33 & 20 & 35 & 20 & 4 & 15 & 40 & 35 \\
\hline Classification & & 36 & 22 & 28 & 16 & 7 & 27 & 10 & 9 \\
\hline $\begin{array}{l}\text { Basic Reference } \\
\text { Selection of }\end{array}$ & & 45 & 27 & 42 & 24 & 6 & 23 & 19 & 16 \\
\hline $\begin{array}{l}\text { Library Materials } \\
\text { Introduction to }\end{array}$ & & 31 & 19 & 23 & 13 & 8 & 31 & 14 & 12 \\
\hline Library Service & • & 13 & 8 & 33 & 19 & 1 & 4 & 26 & 23 \\
\hline Advanced Courses & & 6 & 4 & 15 & 8 & 0 & 0 & 6 & 5 \\
\hline TOTAL & . & $\overline{164}$ & $\overline{100}$ & $\overline{176}$ & $\overline{100}$ & $\overline{26}$ & $\overline{100}$ & $\overline{115}$ & $\overline{100}$ \\
\hline
\end{tabular}

nations than the average per student, 2.8. Several graduates of College B took exemption tests for advanced courses with very good success. Obviously results such as those in Table 7 help Drexel's Admission Office assess credentials for particular colleges for particular periods of time, at least when the data are statistically significant.

\section{Advanced Courses}

Table 3 shows twenty-seven examinations to have been taken for advanced courses, half of them in 1962 . They made up only 6 per cent of all exemption examinations taken. Table 2 shows their success rate to have been fifteen percentage points above that of other examinations. Most of the students taking these examinations were in Group B, with experience, and most were women, though men were more successful. The practice of allowing students to exempt advanced courses was unusual and not practiced by all faculty members, but ic seems to have brought a much better success ratio than examinations for introductory courses.

\section{Male vs. Female}

When the exemption examination performances of male and female students were considered, it was found that 23 per cent of the students taking examinations were men, about the same as the per cent male in the student body, and that male students took an average of 1.66 examinations each, while women students took an average of 1.97 each. No reason is known for this difference. Men passed 44 per cent of the examinations taken, while women passed

TABLE 7

Examinations Taken by the Graduates of Specific Undergraduate Departments of LIBRARY OF SCIENCE

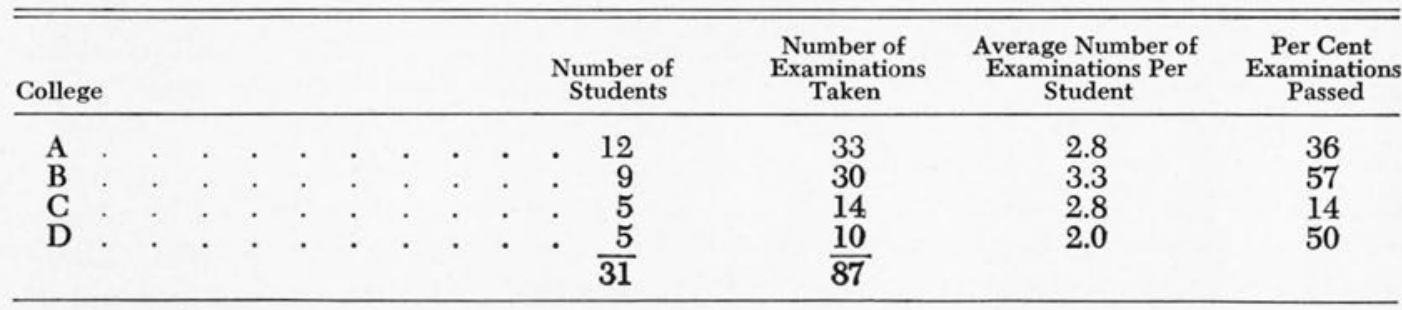


about the same, 48 per cent (see Table 8 ). Women had a higher success rate in each examination except Introduction to Cataloging and Classification, but the two examinations on which women did significantly better than men were Basic Reference and Selection of Library Materials. The frequency with which men and women took the various examinations is remarkably similar (see Table 9 ). The only examination with a variance of more than five percentage points was Selection of Library Materials, which accounted for only 8 per cent of the total number of examinations taken by men but 18 per cent of those taken by women.

Wayne reported males and females at Davis to have passed their examinations with the same percentages in the only other case found in which sex was reported. ${ }^{10}$

\section{Withdrawals vs. Graduates}

There is some literature from both library education and other fields which suggests that students who passed exemption tests also did unusually well scholastically in later course work. This conclusion was touched on at Drexel only remotely, and the conclusions tended to confirm it in a negative direction. Van Der Jagt and Mesner found that students who passed exemption tests at a lower college level also made better

${ }^{10}$ Wayne, op. cit., 308-24.
TABLE 8

Successful Examination Completion RATE FOR MEN AND WOMEN

\begin{tabular}{lcc}
\hline \hline \multicolumn{1}{c}{ Course } & $\begin{array}{c}\text { MEN } \\
\text { Per Cent of } \\
\text { Examinations } \\
\text { Passed }\end{array}$ & $\begin{array}{c}\text { WoMEN } \\
\text { Per Cent of } \\
\text { Examinations } \\
\text { Passed }\end{array}$ \\
\hline $\begin{array}{l}\text { Library in Society } \\
\text { Cataloging and } \\
\quad \text { Classification }\end{array}$ & 54 & 59 \\
$\begin{array}{l}\text { Basic Reference } \\
\text { Selection of Library }\end{array}$ & 27 & 23 \\
$\quad$ Materials & 42 & 61 \\
$\begin{array}{l}\text { Introduction to Library } \\
\text { Service }\end{array}$ & 59 & 22 \\
Advanced Courses & 54 & 68 \\
$\quad$ TOTAL & $\frac{64}{44}$ & $\frac{49}{48}$ \\
\hline
\end{tabular}

than average grades in upper level courses. ${ }^{11}$ Wayne discovered at the University of California at Davis that students who were given credit for freshman course work after having passed CEEB Advanced Placement Examinations also made better than average grades in their freshman courses. ${ }^{12} \mathrm{Al}$ lison and Bloom also found grades in a specific subject area on an advanced level to be better than average for those students who had passed a test in that area on a lower college level at an earlier than average time. ${ }^{13}$ And finally,

${ }^{11}$ E. Van Der Jagt and D. M. Mesner, "Predictability of Success in College Courses by Accelerating and Non-Accelerating Students as Measured by Scores Made by Entering Freshmen on ACE and Cooperative Reading Tests," Science Education, XL (October 1956), 327-31.

${ }^{12}$ Wayne, op. cit., 308-24.

${ }^{13}$ Allison and Bloom, op. cit., 221-33.

TABLE 9

Frequency with Which Men and Women Took Each Examination

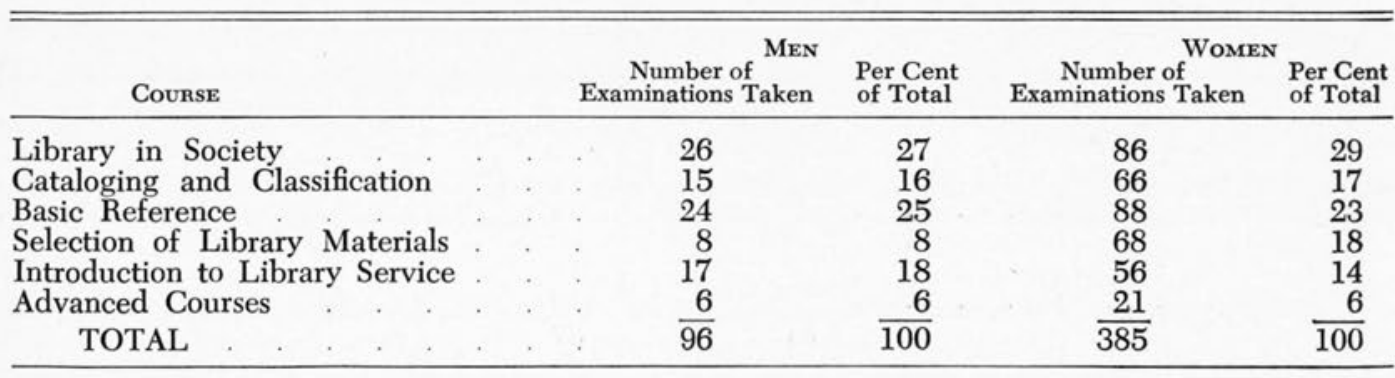


Illinois found its students who exempted core courses to have obtained better grades than average in advanced library science courses. ${ }^{14}$

Sixty-one examinations ( 12 per cent) were taken by Drexel students who later withdrew without completing their degree programs. This included students who failed, who were on probation, and who discontinued course work for personal reasons. Among the students who withdrew, the examination success ratio was only 20 per cent as compared to the overall success rate of 48 per cent, thereby suggesting a positive correlation between examination grades and graduation, or between examination grades and course grades. Nevertheless, a dozen of these students were sufficiently knowledgeable to pass exemption examinations so their loss to the profession was regrettable.

\section{Conclusions}

1. There is some body of literature reporting higher education experience in exemption testing, all of which is favorable to such a program and to the success of well qualified students in it and in later course work.

2. There was a sharp decline in the number of examinations taken between 1962 and 1963 and the following years.

3. There was a steady decline in the percentage of examinations passed, as they became more difficult.
4. Success rate for retests was similar to the overall success rate.

5. There was a general correlation between frequency rate and success rate-the examinations most frequently taken were those most frequently passed.

6. Library in Society, Basic Reference, and Introduction to Library Service were most frequently taken and passed.

7. Students in Group D, with no previous course work or library experience, took the fewest examinations per person and had the highest success rate, though findings in other fields were the opposite.

8. The number of students in Group D taking examinations decreased sharply each year.

9. Of four undergraduate library science departments on which evidence was available, the graduates of two scored somewhat above the overall average, and two scored significantly below.

10. Success percentage on advanced course exemption examinations was significantly higher than the overall coverage.

11. Women did slightly better than men on all but one examination.

12. For students who later withdrew before completing graduation requirements, the success ratio was well below the overall average, suggesting conformity with previous findings.

\footnotetext{
${ }^{14}$ Shearhouse, op. cit., 481-9.
} 